УДК 340.6

DOI https://doi.org/10.32837/pyuv.v0i2(31).562

H. М. Квіm

orcid.org/0000-0002-4823-5541

кандидат юридичних наук, доиент,

доцент кафедри иивільного права та проиесу

Львівського національного університету ілені Івана Франка

\title{
ПРАВОВЕ РЕГУЛЮВАННЯ ВІДНОСИН У БІОМЕДИЧНІЙ СФЕРІ В КОНТЕКСТІ ЄВРОІНТЕГРАЦІЇ
}

Постановка проблеми. Сфера біомедичних досліджень і надання біобанківських послуг як для приватного зберігання та використання, так і в порядку донорства в Україні активно розвивається. Натомість нормативно-правові акти, що регулюють ці відносини, характеризуються фрагментарністю та неузгодженістю. Тим не менше, також можна простежити і позитивні зміни, зокрема у сфері трансплантації, що пов'язано із набранням 31 січня 2019 р. нового Закону України «Про застосування трансплантації анатомічних матеріалів людині» (далі - Закон про трансплантацію). Євроінтеграційні процеси мають значний вплив на розвиток українського законодавства у біомедичній сфері, а саме згідно зі ст. 428 Угоди про асоціацію між Україною, з однієї сторони, та Свропейським Союзом, Свропейським співтовариством з атомної енергії і їхніми державами-членами, з іншої сторони, від 27 червня 2014 р. «Україна поступово наближує своє законодавство та практику до принципів aquis $\mathrm{CC}$, зокрема у сфері інфекційних хвороб, служб крові, трансплантації тканин і клітин <...> Перелік відповідних актів aquis ЄC визначено у Додатку XLI до цієї Угоди». Також ст. 427, ч.1 п. d передбачає співробітництво у сфері якості та безпеки субстанцій людського походження, зокрема крові, тканин і клітин.

Оцінка стану літератури. Різні аспекти проблематики визначення ступеня адаптації чинного законодавства у сфері біомедицини до вимог права ЄС досліджували А.А. Герц, В.М. Коссак, P.А. Майданик, Х.М. Насадюк, Р.О. Стефанчук, I.Я. Сенюта, X.P. Терешко, проте існує необхідність аналізу проблемних питань приведення у відповідність законодавства України до європейських стандартів у контексті діяльності зі створення та використання біобанків в Україні.

Мета і завдання. На підставі аналізу положень відповідних Директив ЄС та їх зіставлення із чинним законодавством України визначити ступінь імплементації норм права ЄС у національне законодавство України та виокремити ті питання, які ще потребують уніфікації.

Виклад основного матеріалу. Угода про асоціацію України з ЄС встановлює необхідність уніфікації умов легітимізації результатів наукових досліджень у сфері біології та медицини [1].
Положення глави 22 «Громадське здоров'я» Розділу 5 Угоди про асоціацію вимагають адаптації положень національного законодавства до стандартів ЄС у сфері біомедичних досліджень. Відповідно до вимог у сфері трансплантації та використання людських тканин і клітин поставлено також низку завдань, які мають на меті привести національне законодавство цієї сфери у відповідність до норм і стандартів, що діють у ЄС. Серед них можна назвати такі: встановлення стандартів якості та безпеки для донорства, отримання, перевірки, обробки, консервації, зберігання та розповсюдження людських тканин і клітин; визначення уповноваженого державного органу, відповідального за якість і безпеку трансплантації тканин і клітин людини; встановлення вимог до діяльності (в т. ч. технічних) щодо придбання, отримання, тестування, обробки, зберігання і розподілу тканин і клітин людини відповідно до стандартів ЄС; приведення у відповідність із нормами ЄС ліцензійних умов і процедур ліцензування й акредитації установ, що працюють із тканинами і клітинами людини; врегулювання питання імпорту/ експорту тканин і клітин; узгодження положень чинного національного законодавства з положеннями Директиви в частині створення «установ тканин» і встановлення вимог до їхньої акредитації, призначення персоналу, надання дозволу або ліцензування; посилення санкцій за порушення законодавства в галузі донорства і трансплантації тканин і клітин людини; забезпечення ефективного державного нагляду та контролю за діяльністю установ, що працюють із тканинами та клітинами людини; формування механізму періодичної звітності щодо якості та безпеки трансплантації тканин і клітин людини; створення механізму відстеження переміщення тканин і клітин від донора до реципієнта і навпаки; узгодження чинного національного законодавства з положеннями Директиви в частині технічних вимог щодо донорства, отримання та тестування людських тканин і клітин; розроблення і здійснення заходів з метою стимулювання добровільного та безоплатного донорства тканин і клітин.

Імплементації підлягають норми Директиви 2004/23/ЄС Європейського Парламенту та Ради від 31 березня 2004 р. про встановлення 
стандартів якості та безпеки для донорства, заготівлі, перевірки, обробки, консервації, зберігання та розподілу людських тканин і клітин [2]; Директиви Комісії 2006/17/ЄС від 8 лютого 2006 р. про виконання Директиви 2004/23/ЄС Європейського Парламенту і Ради щодо певних технічних вимог до надання, отримання і тестування тканин і клітин людини [3]; Директиви Комісії 2006/86/ЄС від 24 жовтня 2006 р. про виконання Директиви Європейського Парламенту та Ради 2004/23/ЄС стосовно вимог до можливості відстеження, повідомлення про серйозні негативні реакції та події, а також стосовно певних технічних вимог до кодування, обробки, консервування, зберігання та розподілу тканин і клітин людини [4], які поступово імплементуються в норми національного законодавства України.

Цим процесом керує Міністерство охорони здоров'я України, яке розробило план імплементації вищезазначених Директив. Основними завданнями цього плану є узгодження положень чинного законодавства України з положеннями Директив і впровадження організаційних заходів із метою забезпечення встановлення технічних вимог, стандартів якості та безпеки збору, тестування, обробки, зберігання та розподілу людських тканин і клітин, забезпечення якості та безпеки людських тканин і клітин, запровадження системи якості для установ, які працюють із людськими тканинами та клітинами, відстеження та інформування про серйозні негативні реакції та явища при використанні людських тканин і клітин.

3 метою гарантування високого рівня безпеки та якості людських тканин і клітин необхідно впровадити належні умови ліцензування й ефективного нагляду за дотриманням ліцензійних умов, професійної підготовки працівників, підвищення їхнього професійно-кваліфікаційного рівня. Сьогодні в Україні процес нагляду за безпекою застосування людських тканин і клітин повною мірою законодавчо не врегульований і не впроваджений.

Директива № 2004/23/ЄC є «базовою», а дві інші - прийняті Свропейською Комісією на їі виконання. Директива № 2004/23/ЄС встановлює уніфіковані рамки для забезпечення високих стандартів якості та безпеки донорства тканин і клітин при їх заготівлі, перевірці, обробці, консервації, зберіганні та розподілі. Метою Директиви є застосування всіх можливих засобів захисту у цих процесах, щоб уникнути перенесення інфекційних захворювань при донорстві. Загалом Директива встановлює мінімальні стандарти, тобто Держави-члени ЄС можуть запроваджувати більш строгі вимоги. Директива № 2004/23/ЄС має обмежений обсяг регулювання:

- стосуються тільки людських тканин і клітин (в т. ч. периферичної крові, стовбурових клітин, репродуктивних клітин, пуповинної крові) та виключно їхнього застосування на людях;

- не застосовується до крові та продуктів крові (крім зазначеного вище), трансплантації людських органів чи їх частин, а також використання органів і клітин тварин.

Директива спрямована на заохочення безкоштовного та добровільного донорства, впровадження прозорих стандартів доступу до тканин і клітин (ст. 13). Донорство, проте, не повинне мати на меті одержання прибутку, а будь-яка компенсація за надання клітин або тканин виплачується за чітко визначених умов і може покривати лише витрати, пов' язані з донорством. Директива також встановлює жорсткі вимоги до конфіденційності даних таким чином, щоб донор і реципієнт не могли бути ідентифіковані. Таємниця донорства може бути розкритою лише щодо донорів репродуктивних клітин (ст. 14).

Донор або інші особи, які надають згоду від його імені (наприклад, родичі), перед відбором тканин або клітин обов'язково повинні бути проінформовані про мету донорства, ризики, пов'язані з ним, конфіденційність даних та інші важливі аспекти, перелік яких встановлений у Додатку до Директиви.

Також Директива встановлює необхідність створення так званих «установ тканин» (tissue establishments), системи їхньої акредитації та ліцензування, а також системи повідомлення про серйозні негативні випадки та реакції при відборі, перевірці, обробці, консервації, зберіганні та розподілі тканин або клітин.

Останній важливий аспект, який впроваджує Директива, - це створення системи для ідентифікації людських тканин і клітин для їхнього подальшого простеження із присвоєнням ідентифікаційних кодів донорського матеріалу, а також єдиної Європейської системи кодування, що дозволятиме відстежити тканини та клітини в межах ЄC і зберігати інформацію про головні характеристики та властивості тканин і клітин (ст. 25).

Водночас ст. 28 Директиви № 2004/23/ЄС встановлює обов'язок Свропейської Комісії розробити ряд технічних стандартів для її імплементації: наприклад, щодо системи якості «установ тканин», критерії відбору донора, процедур заготівлі, обробки і тестування тканин і клітин тощо. Саме на виконання цієї вимоги були прийняті Директива Комісії № 2006/17/ЄС та Директива Комісї̈ № 2006/86/ЄС. Директива Комісії № 2006/17/ ЄC встановлює технічні стандарти щодо заготівлі людських тканин та клітин, критеріїв відбору донорів, лабораторних тестів, що вимагаються від донорів, процедури прийняття придбаних тканин і клітин «установою тканин», вимог до безпосереднього надання реципієнтові специфічних тканин і клітин. Директива імплементує міжнародні 
документи в цій сфері - Конвенцію про права людини та біомедицину 1997 р., додаткові протоколи до неї та рекомендації ВООЗ.

Директива Комісії № 2006/86/ЄС встановлює детальні вимоги до акредитації, призначення, надання дозволу або ліцензування «установ тканин», зокрема щодо їхньої організації та управління, персоналу, використовуваних обладнання та матеріалів, устаткування та приміщень, документації та реєстрації даних, а також встановлює вимогу формування системи аудиту якості та безпеки. Також Директива Комісії встановлює умови якості та безпеки тканин і клітин людини під час кодування, обробки, консервування, зберігання та розподілу між установами з охорони здоров'я, де їх застосовуватимуть до організму людини. Крім того, Директива встановлює форми звітності та термінових повідомлень про серйозні негативні випадки та реакції й деталізує інформацію, що міститься у Європейській системі кодування.

Відповідно до плану імплементації основним нормативно-правовим кроком для імплементації Директив в українське законодавство стало прийняття нової редакції Закону про трансплантацію. Варто звернути увагу на те, що ст. 3 Закону про трансплантацію виключає зі сфери його регулювання питання трансплантації репродуктивних клітин, аутотрансплантації та діяльності банків пуповинної крові, що теж входить в обсяг регулювання Директиви.

Сьогодні у Верховній Раді України зареєстровані два альтернативні законопроєкти «Про допоміжні репродуктивні технології» № 8629 і № 8629 1, які були розглянуті Комітетом Верховної Ради з питань охорони здоров'я 23 квітня 2019 р. [5; 6]. Ці законопроєкти покликані врегулювати питання трансплантації та донорства статевих залоз, репродуктивних клітин і живих ембріонів, які сьогодні виключені зі сфери регулювання Закону про трансплантацію та врегульовані наказом М03 України від 09 вересня 2013 р. № 787 про затвердження Порядку застосування допоміжних репродуктивних технологій в Україні, проте ще потребують значного доопрацювання [7]. 3роблено висновок про необхідність імплементації у спеціальне законодавство в цій сфері положень міжнародно-правових актів, а саме: Ов'єдської Конвенції про захист прав і гідності людини щодо застосування біології та медицини (далі - Конвенція про права людини та біомедицину) Ради Європи від 4 квітня 1997 р., підписаної Україною 22 березня 2002 р. [8] щодо допустимості вибору статі майбутньої дитини та забезпечення реалізації принципу заборони комерціалізації людського тіла та його частин. Зауважено, що у жодному із запропонованих законопроєктів не було сформовано дієвих правових механізмів для вирішення питання щодо забезпечення захисту ембріонів, зо- крема від їхнього створення із дослідницькою чи комерційною метою. Також ці законопроєкти не встановлюють чітких умов й порядку подальшого використання / застосування невикористаних із репродуктивною метою ембріонів і їхню утилізацію. Підкреслено неузгодженість норм цих законопроєктів зі ст. 290 Цивільного кодексу України [9] щодо донорства ембріонів, оскільки такий вид донорства взагалі не передбачений нормою про право на донорство повнолітніх, дієздатних осіб.

Положення ст. 2, 13, 23 Директиви 2004/23 ЄC щодо конфіденційності враховано зокрема у новому законі про трансплантацію, постанові Кабінету Міністрів України «Про заходи щодо організації діяльності закладів охорони здоров'я та наукових установ, пов'язаної з трансплантацією органів, тканин і клітин» від 5 вересня 2007 р. № 1100, наказі Міністерства охорони здоров'я України «Про надання живим родинним донором гомотрансплантата для трансплантації» від 10 квітня 2012 р. № 250 [10].

В «Інструкції щодо вилучення анатомічних утворень, тканин, їх компонентів та фрагментів у донора-трупа», затвердженій наказом Міністерства охорони здоров'я України від 25 вересня 2000 р. № 226 [11], враховано положення ст. 2,16 , 20, 28 Директиви 2004/23/СС щодо системи якості, включаючи навчання. Проте потребують додаткового врегулювання питання стосовно вимог і процедури забору тканин та клітин у біобанки тканин і клітин людини.

Положення ст. 31 розділу VII Директиви 2004/23/ЄС враховано у «Порядку перевезення анатомічних матеріалів людини в межах України та вивезення їх за межі України», затвердженого наказом Міністерства охорони здоров'я України від 04 травня 2000 р. № 96 [12] та «Переліку анатомічних утворень, тканин, їх компонентів та фрагментів і фетальних матеріалів, дозволених до вилучення у донора-трупа і мертвого плоду людини», затвердженому наказом Міністерства охорони здоров’я України від 25 вересня 2000 р. № 226 , зареєстроваому в Міністерстві юстиції України 11 жовтня 2000 р. за № 701/4922 [11].

Частково враховано положення ст. 3 розділу 1 Директиви 2004/23/ЄС щодо консервації в «Умовах забезпечення збереження анатомічних матеріалів під час їх перевезення», затверджених наказом Міністерства охорони здоров'я України від 25 вересня 2000 р. № 226 [11].

Попередня редакція закону про трансплантацію у ст. 17 лише містила декларативну норму, яка передбачала, що відомості про реципієнтів, осіб, котрі заявили про свою згоду або незгоду стати донорами у разі смерті, є конфіденційними, але не регулювала процедури, яка б забезпечувала дотримання цих вимог, ані порядку формування відповідних реєстрів. Після прийняття у 2018 р. 
нової редакції Закону про трансплантацію [13] та набрання ним законної сили з 1 січня 2019 р. питання забезпечення конфіденційності, що доти були не врегульовані належним чином, були законодавчо закріплені у ст. 11 цього закону. Ця стаття врегулювала створення Державних інформаційних систем трансплантації, зокрема Єдиної державної інформаційної системи трансплантації органів та тканин і Державної інформаційної системи трансплантації гемопоетичних стовбурових клітин, врегулювавши інформаційне забезпечення надання медичної допомоги із застосуванням трансплантації та здійснення діяльності, пов'язаної із трансплантацією. На основі названих систем повинні бути сформовані бази даних і реєстри, що повною мірою відповідатиме вимогам європейського законодавства щодо створення системи кодування, яка дасть змогу відстежувати тканини і клітини на всіх стадіях трансплантації.

Вимоги ст. 7 розділу II Директиви 2004/23/ЄC враховано у наказі Міністерства охорони здоров'я України 10 липня 2014 р. № 481 «Про затвердження Порядку забору та тимчасового зберігання пуповинної (плацентарної) крові та / або плаценти» [14].

Висновки i перспективи подальших досліджень. Чинне законодавство України потребує узгодження зі ст. 16 Директиви 2004/23/ЄС щодо проведення попереднього обов'язкового медичного огляду живого донора та ст. 28 цієї ж Директиви в контексті доповнення критеріїв відбору донорів тканин і клітин та проведення необхідних лабораторних перевірок. Водночас потребує доопрацювання в частині встановлення вимог відповідно до ст. 28 розділу VI Директиви 2004/23/СC щодо процесу підготовки тканин, їхньої обробки та розподілу прямої поставки окремих тканин i клітин реципієнту.

Потребують приведення у відповідність до ст. 4 розділу I Директиви 2004/23/ЄС накази Міністерства охорони здоров'я України:

від 11 грудня 2006 р. № 812 «Про затвердження Положення про Координаційний центр трансплантації органів, тканин і клітин» [15];

від 10 жовтня 2007 р. № 630 «Про затвердження Порядку проведення клінічних випробувань тканинних і клітинних трансплантатів та експертизи матеріалів клінічних випробувань й унесення змін до Порядку проведення клінічних випробувань лікарських засобів та експертизи матеріалів клінічних випробувань, затвердженого наказом Міністерства охорони здоров'я України від 13 лютого 2006 р. № 66, зареєстрованого в Мiністерстві юстиції України 10 березня 2006 р. за № 252/12126» [16];

від 2 березня 2016 р. № 285 «Про затвердження Ліцензійних умов провадження господарської діяльності з медичної практики» [17]; від 20 квітня 2012 р. № 276 «Про затвердження Переліку тканин і клітин людини, з якими дозволена діяльність банків пуповинної крові, інших тканин і клітин людини» [18].

Отже, українське законодавство необхідно привести у відповідність до Директив у тому, що стосується запровадження системи якості в установах, які працюють із людськими тканинами та клітинами, включаючи навчання персоналу, процедури повідомлення про серйозні негативні випадки та реакції, інформування донорів і їх обстеження перед забором тканин або клітин. Крім того, необхідно доповнити критерії відбору донорів, доопрацювати стандарти щодо підготовки тканин і клітин, їхньої обробки та розподілу прямої поставки окремих тканин і клітин реципієнту.

Імплементація положень директив $\mathrm{CC}$ і використання позитивного законотворчого досвіду іноземних держав гарантуватиме дотримання цілей Директив, якими передбачена необхідність встановлення технічних вимог, стандартів якості та безпеки збору, тестування, обробки, зберігання та розподілу людських тканин і клітин, забезпечення якості та безпеки людських тканин і клітин, запровадження системи якості для установ, які працюють із людськими тканинами і клітинами; забезпечить реалізацію законодавчих, інституційних, організаційних і технічних змін із метою підвищення рівня безпеки людських тканин і клітин, відстеження та повідомлення про серйозні побічні реакції та події й узгодження положень чинного законодавства України з положеннями Директив щодо якості людських тканин і клітин; сприятиме забезпеченню належних вимог ліцензування, інспектування та контролю у сфері забезпечення i використання людських тканин і клітин та діяльності щодо створення та використання біобанків.

\section{Jimepamypa}

1. Угода про асоціацію між Україною, з однієї сторони, та Європейським Союзом, Європейським співтовариством з атомної енергії і їніми державами-членами, 3 іншої сторони [Угоду ратифіковано Законом № 1678-VII від 16 вересня 2014 p.] URL: https://zakon.rada.gov.ua/laws/show/984_011 (дата звернення: 19.06.2020)д

2. Директива 2004/23/СС Європейського Парламенту та Ради від 31 березня 2004 р. про встановлення стандартів якості та безпеки для донорства, заготівлі, перевірки, обробки, консервації, зберігання та розподілу людських тканин і клітин. URL: http://docs.pravo.ru/do-cument/view/28859619 (дата звернення: 19.06.2020).

3. Директива Комісіі $2006 / 17 / € C$ від 8 лютого 2006 р. про виконання Директиви 2004/23/ЄС Європейського Парламенту і Ради щодо певних технічних вимог до надання, отримання і тестування тканин і клітин людини. URL: https://eur-lex.europa.eu/legal-content/ $\mathrm{EN} / \mathrm{TXT} /$ ?qid=1426191222409\&uri=CELEX:0200 6L0017-20121217 (дата звернення: 19.06.2020).

4. Директива Комісії $2006 / 86 / \mathrm{EC}$ від 24 жовтня 2006 р. про виконання Директиви Європейського 
Парламенту та Ради 2004/23/СС стосовно вимог до можливості відстеження, повідомлення про серйозні негативні реакції та події, а також стосовно певних технічних вимог до кодування, обробки, консервування, зберігання та розподілу тканин і клітин людини. URL: https://eur-lex.europa.eu/legal-content/EN/TXT/?uri= CELEX\% 3A32006L0086 (дата звернення: 19.06.2020).

5. Про допоміжні репродуктивні технології Проєкт Закону України № 8629 від 19 липня 2018 р. URL: https://ips.ligazakon.net/document/JH6NP00A (дата звернення: 19.06.2020).

6. Про допоміжні репродуктивні технології Проєкт Закону України № 8629-1 від 01 серпня 2018 p. URL: http://w1.c1.rada.gov.ua/pls/zweb2/ webproc4_1?pf3511=64502 (дата звернення: 19.06.2020).

7. Про затвердження Порядку застосування допоміжних репродуктивних технологій в Україні : наказ Міністерства охорони здоров'я України від 09 вересня 2013 p. № 787. URL: https://zakon.rada.gov.ua/laws/ show/z1697-13 (дата звернення: 19.06.2020).

8. Конвенція про захист прав і гідності людини щодо застосування біології та медицини Ради Європи від 4 квітня 1997 p. URL: https://zakon.rada.gov.ua/laws/ show/994 334\#Text (дата звернення: 19.06.2020).

9. Цивїльний кодекс України від 16 січня 2003 р. № 435-IV. Відолості Верховної Ради Украӥни. 2003. № 40-44. URL: http://zakon2.rada.gov.ua/la-ws/show/ 435-15 (дата звернення: 19.06.2020).

10. Про заходи щодо організації діяльності закладів охорони здоров'я та наукових установ, пов'язаної з трансплантацією органів, тканин і клітин: Постанова Кабінету Міністрів України від 05 вересня 2007 р. № 1100-2007-п. URL: https://zakon.rada.gov.ua/laws/ show $/ 1100-2007-\%$ D0\% BF (дата звернення: 19.06.2020).

11. Про затвердження нормативно-правових документів з питань трансплантації : наказ Міністерства охорони здоров’я України від 25 вересня 2000 р. № 226 URL: https://zakon.rada.gov.ua/laws/show/z0697-00 (дата звернення: 19.06.2020)д

12. Про затвердження нормативно-правових актів 3 питань трансплантації органів та інших анатомічних матеріалів людині : наказ Міністерства охорони здоров’я України від 04 травня 2000 р. № 96. URL: https://zakon.rada.gov.ua/laws/show/z0682-00\#Text (дата звернення: 19.06.2020)

13. Про застосування трансплантації анатомічних матеріалів людині: закон України від 17 травня 2018 р. № 2801-12 URL: https://zakon.rada.gov.ua/laws/show/ 2427-19 (дата звернення: 19.06.2020).

14. Про затвердження Порядку забору та тимчасового зберігання пуповинної (плацентарної) крові та/або плаценти: наказ Міністерства охорони здоров’я України від 10 липня 2014 р. № 481 URL: https://zakon.rada.gov.ua/laws/show/z0869-14 (дата звернення: 19.06.2020).

15. Про затвердження Положення про Координаційний центр трансплантації органів, тканин і клітин: наказ Міністерства охорони здоров'я України від 11 грудня 2006 р. № 812. URL: https://zakon.rada.gov.ua/ laws/show/z1380-06 (дата звернення: 19.06.2020).

16. Порядок проведення клінічних випробувань тканинних і клітинних трансплантатів та експертизи матеріалів клінічних випробувань: наказ Міністерства охорони здоров’я України від 10 жовтня 2007 р. № 630. URL: https://zakon.rada.gov.ua/laws/show/z1206-07 (дата звернення: 02.03.2020).

17. Про затвердження Ліцензійних умов провадження господарської діяльності з медичної практики : постанова Кабінету Міністрів України від 2 бе- резня 2016 р. № 285. URL: https://zakon.rada.gov.ua/ la-ws/show $/ 285-2016-\%$ D0\% BF (дата звернення: 19.06.2020)

18. Про затвердження Переліку тканин і клітин людини, з якими дозволена діяльність банків пуповинної крові, інших тканин і клітин людини: наказ Міністерства охорони здоров'я України від 20 квітня 2012 р. № 276. URL: https://zakon.rada.gov.ua/la-ws/show/ z1124-12 (дата звернення: 19.06.2020).

\section{Анотація}

Квіт Н. М. Правове регулювання відносин у біомедичній сфері в контексті євроінтеграції. - Стаття.

Стаття присвячена аналізу проблемних питань приведення у відповідність законодавства України до європейських стандартів у контексті діяльності зі створення та використання біобанків в Україні. На підставі аналізу положень відповідних Директив ЄC і їх зіставлення із чинним законодавством України визначено ступінь імплементації норм права ЄС у національне законодавство України та виокремлено питання, які ще потребують уніфікації.

Автор наголошує на важливості прийняття нової редакції Закону про трансплантацію, як нормативно-правового кроку для імплементації Директив в українське законодавство. Виключення ст. 3 Закону про трансплантацію зі сфери його регулювання питання трансплантації репродуктивних клітин, аутотрансплантації та діяльності банків пуповинної крові, що входить в обсяг регулювання Директиви, не сприяє процесу адаптації українського законодавства до європейських стандартів.

Аналізуючи правове регулювання репродуктивної медицини одного із видів діяльності управителів біобанків в Україні, зроблено наголос на тому, що сьогодні ані в чинному законодавстві, ані в законопроєктах не сформовано дієвих правових механізмів для вирішення питання щодо забезпечення захисту ембріонів, зокрема від їхнього створення із дослідницькою чи комерційною метою, не встановлено чітких умов і порядку подальшого використання / застосування невикористаних із репродуктивною метою ембріонів і їхньої утилізації.

Зроблено висновок про те, що українське законодавство необхідно привести у відповідність до Директив в тому, що стосується запровадження системи якості в установах, які працюють із людськими тканинами та клітинами, включаючи навчання персоналу, процедури повідомлення про серйозні негативні випадки та реакції, інформування донорів і їх обстеження перед забором тканин або клітин. Також необхідно доповнити критерії відбору донорів, доопрацювати стандарти підготовки тканин і клітин, їхньої обробки та розподілу прямої поставки окремих тканин і клітин реципієнту.

Ключові слова: правове регулювання, біобанк, безпека тканин і клітин, право ЄС, євроінтеграція.

\section{Summary}

Kvit $N$. M. Legal regulation of relations in the biomedical sphere in the context of European integration. Article.

The article is devoted to the analysis of problematic issues of bringing the legislation of Ukraine in line with European standards in the context of activities for the creation and use of biobanks in Ukraine. Based on the analysis of the provisions of the relevant EU Directives and their comparison with the current legislation of Ukraine, the degree of implementation of EU law into the national 
legislation of Ukraine is determined and issues that still need unification are identified.

The author emphasizes the importance of adopting a new version of the Law on Transplantation as a legal step for the implementation of the Directives in Ukrainian legislation. In this case, the exclusion in Art. 3 of the Law on Transplantation in the field of its regulation of reproductive cell transplantation, autotransplantation and the activities of umbilical cord blood banks, which is included in the scope of regulation of the Directive does not contribute to the process of adapting Ukrainian legislation to European standards.

Analyzing the legal regulation of reproductive medicine in one of the activities of biobank managers in Ukraine, it is emphasized that today neither the current legislation nor the draft laws have effective legal mechanisms to address the protection of embryos, in particular from their creation with research or There are no clear conditions for the commercial use and procedure for further use / use of embryos not used for reproductive purposes and their disposal.

It is concluded that Ukrainian legislation needs to be brought in line with the Directives regarding the implementation of a quality system in institutions working with human tissues and cells, including staff training, procedures for reporting serious adverse events and reactions, informing donors and their examination before sampling of tissues or cells. It is also necessary to supplement the criteria for donor selection, to refine the standards for the preparation of tissues and cells, their processing and distribution of direct delivery of individual tissues and cells to the recipient.

Key words: legal regulation, biobank, tissue and cell safety, EU law, European integration. 